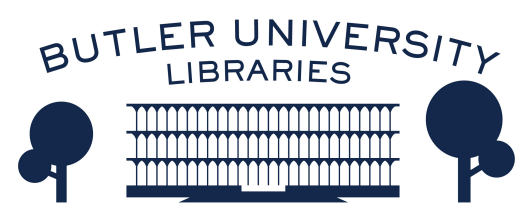

Journal of Hindu-Christian Studies

Volume 26

Article 10

November 2013

\title{
Sacred Orality, Sacred Dialogue: Walter J. Ong and the Practice of Hindu-Christian Studies
}

Reid B. Locklin

St. Michael's College, University of Toronto

Follow this and additional works at: https://digitalcommons.butler.edu/jhcs

Part of the Religion Commons

\section{Recommended Citation}

Locklin, Reid B. (2013) "Sacred Orality, Sacred Dialogue: Walter J. Ong and the Practice of Hindu-Christian Studies," Journal of Hindu-Christian Studies: Vol. 26, Article 10.

Available at: https://doi.org/10.7825/2164-6279.1549

The Journal of Hindu-Christian Studies is a publication of the Society for Hindu-Christian Studies. The digital version is made available by Digital Commons @ Butler University. For questions about the Journal or the Society, please contact cbauman@butler.edu. For more information about Digital Commons @ Butler University, please contact digitalscholarship@butler.edu. 
Locklin: Sacred Orality, Sacred Dialogue

\title{
SACRED ORALITY, SACRED DIALOGUE: WALTER J. ONG AND THE PRACTICE OF HINDU- CHRISTIAN STUDIES
}

\author{
Reid B. Locklin \\ St. Michael's College, University of Toronto
}

THE genesis of this essay can be traced to two specific events from my own personal history. ${ }^{1}$ One summer, when I had just finished coursework in my doctoral program and was looking forward to my thesis, I took a retreat at Arsha Vidya Gurukulam, a Hindu ashram in the Pocono Mountains region of eastern Pennsylvania. Before one of the discourses that constituted the retreat, a lay devotee of the Arsha Vidya movement stood to offer a testimonial to the Gita Home Study Program, published by the ashram press. ${ }^{2}$ The study program itself is pretty simple: the text consists of sections of the popular Hindu scripture Bhagavad-Gitā, along with discourses by Swami Dayananda Saraswati, the chief guru of the ashram. Members of the movement form groups of between 4-10 people for shared study. ${ }^{3}$

What was of greater interest to me was the way that the study group was presented by the lay devotee. It was not, the presenter insisted, like a book group, in which people read works separately and then come together to discuss. Instead, each study group would gather, one person would volunteer to read out loud, and then, in the process of reading, that person would become the guru. There was nothing supernatural here, she explained, but simply the fact that, when the discourses on the Gita were read aloud, it was "like the guru is present there in the group." Hence, the study group could function efficaciously to transmit the teaching of liberation, in a way that private study, in the absence of a guru, never could.

This anecdote is interesting to me-well over a decade later-for a number of reasons. First of all, of course, it reveals something about the transformations of diaspora Hinduism in the contemporary period, as middle class Hindus navigate the dual forces of a radically democratized tradition of guru-

Reid B. Locklin holds an associate professorship in Christianity and the Intellectual Tradition, a joint appointment at Saint Michael's College and the Department for the Study of Religion, University of Toronto. A graduate of Boston University and Boston College, he is the author of Spiritual but Not Religious? (Liturgical Press, 2005), Liturgy of Liberation (Peeters, 2011) and other works in comparative theology, Hindu-Christian studies, and spirituality. He was president of the Society for HinduChristian Studies from 2009 to 2010, and he currently serves on the steering committee for the Conference on the Study of the Religions of India and on the Board of Directors for the College Theology Society. He can be reached at reid .locklin@utoronto.ca. 
disciple relationships and the natural limits of such relationships outside of the elite, Brahminical circles in which they originally flourished. ${ }^{4}$ The guru is, in this situation, both radically available to any person, regardless of gender, caste or ethnicity, and, partially as a consequence of this near-universal availability, necessarily absent in the experience of most such disciples most of the time. The solution? An opportunity to make that absent guru present while absent, through the repeated practice of embodied speech.

The reference to embodied speech suggests a second line of inquiry, and takes me to the second event at the source of this essay. Some six years before I visited Arsha Vidya Gurukulam, I was sitting in a cold trailer on the Pine Ridge Reserve in South Dakota, drinking coffee with a Jesuit mission priest. He leaned back, offered a smug grin, and asked: "What is the opposite of literacy?" Presumably, he expected me to answer, "illiteracy." As a student of English composition from East Tennessee, however, I blinked, and gave what I thought was the much more obvious answer, rooted in the work of the mid-twentiethcentury cultural theorist-and fellow JesuitWalter J. Ong: "orality.” My interlocutor nearly fell out of his chair.

Only recently have I begun to try to connect these two events, one an experience with the transformation of oral patterns of communication in the Hindu tradition of Advaita Vedānta, and the second an experience with the theory of orality advanced by Ong. Does the latter theory have something to say to the former, historical transformation of Hindu tradition and indeed for the broader practice of Hindu-Christian studies? I have begun to think that it might, and I am not alone. In this essay,
I propose first to explore selected aspects of Ong's description of the oral sensorium, with special attention to its attraction for the analysis of a Hindu tradition like that represented at Arsha Vidya Gurukulam. Then, in a second section, I will touch on two attempts to bring orality into the study of Hindu and Christian traditions: Harold Coward's comparative study of scripture and my own recent volume, Liturgy of Liberation. A serious encounter with the theory of orality, I suggest, opens a useful area for study across Hindu and Christian traditions, as well as challenging a number of assumptions around language, culture and academic objectivity that form a broad context for shared study.

\section{The Oral Sensorium: Authority, Personal Presence, and Interiority}

In his landmark 1964 Terry lectures at Yale University, published in 1967 as The Presence of the Word, Walter Ong makes a brief but telling reference to the "Hindu insistence that for true wisdom it is essential that one learn not merely from books but from the spoken word received personally from a guru." ${ }^{5}$ Later, in Orality and Literacy, he again takes up Hindu tradition, this time focusing on common claims about verbatim memorization of Vedic hymns. ${ }^{6}$ It has been well-recognized that the preferred mode of transmission of the Vedas and many other sacred texts in Brahminical tradition, both before and after these texts were fixed in writing, has been by means of oral memorization, and such memorization carries many of the marks of oral memory noted by Ong: an emphasis on metrical formulae, for example, copious cross-references to other, closely related textual traditions, and musical constraints. Thus, in recitation of Sanskrit 
texts, teachers insist not only on the correct words, but the correct rhythm and tone of their recitation. ${ }^{7} \quad$ Ong's primary interest in discussing these Hindu traditions, we should note, is to challenge the oft-repeated claim that such memorization is truly verbatim and the text thus reproduced invariable. Such claims, though frequently insisted upon in oral cultures, are almost always contradicted to a greater or lesser extent in actual practice... including, in Ong's account, the practice of Vedic recitation. ${ }^{8}$

What Ong does not discuss in these worksor anywhere, to the best of my knowledge-are the specific features of orality that may help explain its persistence in what must be admitted to be one of oldest literate religious cultures of the world. Based on my work with the non-dualist Hindu tradition of Advaita Vedānta in places like Arsha Vidya Gurukulam or the various centers of the worldwide Ramakrishna and Chinmaya Missions, at least three such aspects commend themselves as being of particular relevance: oral patterns of authority, the central importance of personal presence, and the close association between sound and interiority.

First, authority. Early in The Presence of the Word, Ong notes a correlation between the oral sensorium and authoritarianism, particularly in the rhetoric of those modern reformers who have proclaimed the liberation, through print culture, of persons and indeed whole societies previously held captive by churchmen or school teachers. ${ }^{9} \quad$ Though Ong categorically rejects any such conspiracy theories of history, he does concede a kind of traditionalism and authoritarianism associated with oral patterns of communication. Since oral knowledge depends, by its very nature, on continual repetition, it is by nature conservative and tends to place relatively low value on originality. ${ }^{10} \quad$ Since such knowledge also depends upon social structures and personal relationships, it becomes what ong calls a "tribal possession," maintained not by contact with the "objective world" as such, but with traditional discourse about that world. ${ }^{11}$ Perhaps most importantly, the verbal word carries an authority and reliability of its own that eludes the printed word, at least in Ong's analysis. "One prefers what is verbally reported to what is seen," he writes, "correlating the two relatively slightly." Quoting Ambrose of Milan, he underscores the point: "Sight is often deceived, hearing serves as guarantee." ${ }^{12}$

According to Ong, such authority stems primarily from the commanding presence of the word itself, a presence that belongs to embodied speech of its own nature, as a performative event. Nevertheless, it is also true that personal presence and interpersonal relations represent important aspects of oral cultures, particularly in comparison to more literate, visualist ones. At one level, an emphasis on personal presence follows rather directly from the fact that presence, as such, is simply what is required for oral communication to take place: speaking, hearing and dialogue depend upon some form of personal presence, no matter how it is mediated. The interactions that characterize such dialogue are often agonistic, involving some level of mutual questioning or contestation, but they nevertheless bind persons into groups and situate words and understandings in contexts that are "personinteractive."13 More than this, personal presence also shapes the way that persons 
relate to the nonhuman world and the universe of ideas, insofar as the acquisition of knowledge is normed as an achievement of empathy, participation and personal identification with that which is known. ${ }^{14}$ Ong scholar Thomas J. Farrell characterizes this as an "alternative approach to knowledge through voice and sound. This alternative approach considers knowledge in terms of dialogue, as emerging from dialogue." ${ }^{15}$

The two points I have highlighted so farauthority and personal presence-resonate well with my experiences of Advaita tradition, as this tradition has been reinvented and sustained in its new global context. The "residual" or "secondary" orality revealed in retreats, discourses and initiatives like the Bhagavad Gita Study Program does not, in my judgment, represent merely a nostalgic holdover from a real or imagined past; instead, it may be seen as shaping patterns of authority, deploying discursive structures to solidify group identity in a pluralistic context, and thus offering a deeply traditional, counter-cultural orientation to knowledge itself. That is, it styles such knowledge less in terms of objectification, commodification and consumption, and more in terms of the conformation of disciple to teacher and personal identification of both disciple and teacher with the higher, divine reality of àtman.

This last point about personal identification with ätman leads to another aspect of Ong's analysis that may resonate distinctively well with this teaching tradition: that is, the close correlation he draws between sound and interiority. The interiority of sound, for Ong, draws together several dimensions of the experience of hearing. Sight renders space an empty medium between the eye and a particular object; sound renders space a vast interior, a living reality, continuously inhabited by voices, music and noises of various kinds. ${ }^{16}$ sight isolates and dissects, while sound incorporates and unifies. ${ }^{17}$ Whereas sight reaches only to the surfaces of things, sound penetrates them without violation, such as when one taps on a box to find out if it is full or rings "a coin to learn whether it is silver or lead." ${ }^{18}$ It also binds interiors to one another, as sounds echo and resonate with one another. ${ }^{19}$ Most importantly, the interiors thus penetrated and bound together include the existential "interiors" of human selves, insofar as sound originates from within the human body, penetrates it, and envelopes it from every side. $^{20}$ "You can immerse yourself in hearing, in sound," Ong observes. "There is no way to immerse yourself similarly in sight." 21

The resonance between Ong's account and patterns of discourse in the Hindu tradition of Advaita is, perhaps, most well illustrated with reference to the celebrated conversation between the sage Yàjñavalkya and King Janaka in the Brhadāranyaka Upanișad (BU 4.3). ${ }^{22}$ In this account, the king asks, "Yājñavalkya, what is the source of light for a person here?" The sun, replies the sage, for "it is by the light of the sun that a person sits down, goes about, does his work, and returns" (4.3.2) The king presses the question: what about when the sun has set? Then the moon is the source of light, and thus of life (4.3.3). When the moon has set? Then the fire (4.3.4). When the fire has died out? The sage answers,

The voice is . . his source of light. It is by the light of the voice that a person sits down, goes about, does his work, and returns. Therefore, your Majesty, when someone cannot make out even his own 
hand [with his eyes], he goes straightaway towards the spot from where he hears a voice (4.3.5).

And what about when the voice is stilled? Then the light for a person, and the source of her life, is the atman (4.3.6). A discourse on this atman follows at some length, culminating in the declaration, "this is the immense and unborn self, unageing, undying, immortal, free from fear-the brahman. Brahman surely is free from fear, and a person who knows this undoubtedly becomes that brahman that is free from fear" (4.4.25).

This account is a good example of what Jacqueline G. Suthren Hirst calls a "method of interiorization," paradigmatic not only for the Upanișads, but also for later Advaita teaching. ${ }^{23}$ In this particular narrative, as we have seen, such interiorization no doubt employs visual imagery and begins solidly in the world of sight. But the path to the true, interior self of all beings-that is, the path to liberationnecessarily proceeds by means of the voice and the world of sound, which persist even when the ostensibly objective, externalized world of visual experience has gone completely dark.

\section{Orality, Dialogue and the Practice of Hindu-Christian Studies}

Once one begins to appreciate the fundamentally oral character of Advaita and many other Hindu traditions, the visualist and literate character of much work in interreligious theology and Hindu-Christian studies in particular becomes very striking. Though it deals with Indian Buddhism rather than Hinduism, for example, Paul J. Griffiths' Religious Reading: The Place of Reading in the Practice of Religion represents a good case in point. $^{24}$ This work reveals a number of affinities with Ong's theory, not least in Griffiths' desire to encourage what he styles a "severer listening" to our sacred texts as an alternative to more consumerist reading strategies typical of the modern academy. ${ }^{25}$ Griffiths nevertheless styles such "listening" in primarily visualist terms as reading, re-reading and rote memorization. The work of Francis X. Clooney well illustrates a further turn toward the literate, as he leans strongly on the postmodern literary theories of a Jacques Derrida or a Charles Altieri to interpret Hindu and Christian traditions which, though certainly committed to written form, equally certainly trace their origins and continuing reappropriation to cultures that retain a strong oral character. ${ }^{26}$ It can hardly be doubted that much is gained by studies such as these. But is something also lost? Or, perhaps better, can a re-appropriation of the distinctive thoughtforms and practices of primary oral cultures open new avenues and alternative points of view?

One scholar who has explored this question in some depth is Harold Coward, founder of this Society and former director of the Centre for Studies in Religion and Society at the University of Victoria. Coward's career has spanned some 35 years, beginning with his first book on the Indian grammarian Bhartrhari in 1976, and spans diverse topics of inquiry, including the philosophy of language, HinduChristian study and dialogue, the interpretation of religious pluralism, and a wide range of edited, interdisciplinary projects in social ethics, science and religion, and ecology. ${ }^{27}$

Across much of this work, Coward is preoccupied with distinctively Hindu philosophies and theologies of sacred sound. 
He reports discovering the power of orality in his early studies with T.R.V. Murti, first at McMaster University and then continuing at Banaras Hindu University. ${ }^{28}$ Coward recalls Murti's fury when, after delivering a number of lectures from memory, without notes, Coward had the temerity to ask him to recommend a book for further reading. Such a book existed: Murti himself had written it! so why did he scold his student instead of suggesting his own book? "Because," Coward writes, "[Murti] was committed to the traditional Sanskrit position on the superiority of the oral over the written.... Books and the written tradition were clearly secondary-for those who were too stupid to learn from oral teaching, and to remember!"29 For Coward, Murti embodied the traditional Sanskrit pattern of guru-śisya relationships, not only in his oral lecture style, but also in his insistence that, to understand a written text such as the Yoga Sütras, one had to work through it line-by-line, reciting the sūtra out loud, discussing it in the context of the teachings of major philosophical rivals, and testing one's understanding orally, and repeatedly, until the teacher could verify that the sūtra had been properly understood. ${ }^{30}$

This initial experience of oral instruction was reinforced by further studies in the sphota theory of meaning advanced by Bhartrhari and in the recitation of mantras in the Yoga of Patañjali, both of which helped Coward reflect more deeply on the function of language, especially spoken language, to reveal the divine. $^{31}$ In their major work on the grammarians, Coward and K. Kunjunni Raja identify the oral character of Indian traditions as one of the primary reasons behind such religious thinkers' strong emphasis upon the word (śabda) and its proper analysis (vyākarana) as uniquely efficacious means of final liberation. ${ }^{32}$ "For Vyākarana," they write, ". . . spoken language is the medium through which Śabda Brahman is manifested, and the Vedas are the criterion expression of that manifestation." ${ }^{33}$ Through grammatical analysis, one purifies one's speech from corruptions, suppresses the sequencing of thoughts and sounds in temporal order and, in so doing, frees language itself from the various conventional uses to which it is habitually subjected by the embodied ego. ${ }^{34}$ When language has been set free from ego and attachment, the inner vision of the spiritual seeker also follows in due course. ${ }^{35}$ In the more popular work Mantra: Hearing the Divine in India and America, Coward and his co-author David J. Goa generalize the grammarians' account of liberation to comprehend a broader, distinctively Hindu theology of sacred sound:

Hearing and saying the mantra is an act of worship that 'tunes' one to the basic sound or vibration of the universe. By continual hearing and chanting, one purifies and transforms one's life until it vibrates in harmony with the divine, which is itself pure sound. ${ }^{36}$

Echoing Ong's sense of the interiority of sound and its intrinsic authority, coward attributes to the spoken word a unique, transforming presence unavailable to the written word.

For Coward, this discovery of the transformative power of the spoken word had consequences not only for his studies of Hinduism, but also his comparative work. This is perhaps most clearly articulated in his 1988 study Sacred Word and Sacred Text-which, when released in a revised edition under the title Scripture in the World Religions, carried an 
endorsement from no less an authority than Walter J. Ong. In this work, Coward surveys the scriptural traditions of Judaism, Christianity, Islam, Hinduism, Sikhism and Buddhism, attentive in each case both to the primacy of the oral in the communication and reception of scripture and to the creative interplay of oral and written expression, once these scriptures are committed to writing. On Coward's hearing, Hinduism alone has consistently devalued the written text in favor of oral tradition; hence, Hinduism serves as a catalyst for rediscovering the sacred orality of other scriptures and other traditions. ${ }^{37}$ It is the spoken word, Coward insists, that possesses authentic creative power, and the spoken word that can flexibly adapt to encounter its hearers - in Judaism and Christianity no less than in Hinduism. ${ }^{38}$ "The recitation and preaching of the word," he writes, "evokes the truth of the Divine, which transcends all words." 39 When, on the other hand, scripture "is learned and nourished only through written and read materials without an underlying oral foundation ... then the written scripture will be empty of spiritual power." 40 Writing has its place, in Coward's view, insofar as it facilitates preservation of the scriptures, as well as their scholarly analysis. But only oral performance holds the key to authentic religious transformation.

Coward notes, again echoing Ong, that one element that renders the spoken word so effective for spiritual transformation is the context of personal presence and personal relationship that it invariably requires. ${ }^{41}$ The personal-interactive character of oral performance became the main focus of my own recent volume, Liturgy of Liberation. As a Christian theological commentary on the
Upadeśasāhasrī or Thousand Teachings of Ādi Śankarācārya, Liturgy of Liberation explores Śankara's strong claim that liberating knowledge arises only through samvāda, or spoken dialogue. Such dialogue includes individual, meditative recitation, of course, but it also involves philosophical debate, skilful deployment of a well-traveled fund of scriptural sentences, explanatory illustrations and poetic tropes, and even spirited polemic with the rhetorical exponents of rival schools. ${ }^{42}$ At one level, then, the tradition aims for sublime isolation and identification with àtman, with that divine reality at the core of each and every conscious being; at another, more performative level, the tradition cultivates such self-knowledge through a complex tapestry of oral practices and constant engagement with both rhetorical and actual others-including that highest, metaphysical "other" that is the prospective disciple's own divine atman. ${ }^{43}$ In and out of a sustained hearing of this text, I contend, it becomes possible to reimagine both Christ and the Christian life as a divine samvāda, in which the presence of God can be discerned not merely in sound itself, but in the difficult, sacred work of interpersonal dialogue, intense contestation and continual reconciliation. ${ }^{44}$

These two attempts to bring orality into comparative studies of Hinduism and Christianity have at least one feature in common: both focus primarily on how recognition of the fundamentally oral character of these Hindu traditions may help us encounter both these and other traditions in a new way. For Coward, this involves a rediscovery of the oral roots of all scripture and a recovery of their transformative power for persons of all faiths; for me, it entails 
something closer to a renewed Christian mystagogical practice, modeled upon the dynamics witnessed in this very particular, eighth-century Hindu text. In neither case, perhaps, do we find sustained reflection on what a more thorough retrieval of oral culture and the oral-aural sensorium might mean for the scholarly practice of Hindu-Christian studies itself.

\section{Conclusion: A Deeper Notion of Objectivity}

Thus far, this essay has traced major features of Walter J. Ong's theory of orality and two attempts to retrieve his insights and to reimagine the scholarly practice of HinduChristian studies. To conclude, I would like briefly to suggest two possible further consequences for the discipline suggested by Ong's work:

- First, one obvious but still important consequence of Ong's analysis is the reminder that texts and traditions bear the indelible mark of the cultures in which they were produced. Importantly for his own scholarly project, this includes not merely differences of language and geography, but also assumptions about reality and knowledge governed by the dominant sensorium. In his Presence of the Word, for example, Ong suggests a number of ways that a recognition of oral patterns might re-contextualize the controversies of the Protestant and Catholic Reformations and, thus, advance the cause of Christian ecumenism. ${ }^{45}$ Similarly, a rediscovery of orality might help re-contextualize the condemnations and polemics typical of many Christian scriptural texts and many
Hindu traditions of interpretationincluding, of course, even such great lights as Bhartṛhari, Patañjali, and Ādi Śañkarācārya.

- Second, Ong invites us to reconsider the objectivity of our notions of objectivity. When confronted with apparent contradictions between a doctrinal statement from one tradition, for example, and a philosophical argument from another, we might consider whether some of the fixity we attribute to one or the other artifact stems not from their "objective" truth, as such, but from our own visualist orientations. Ong helpfully draws our attention the spontaneous free play of speech and the intrinsically openended character of authentic dialogue. ${ }^{46}$ More than this, he notes that, in oral-aural cultures, objectivity consists not in the purported fixity of one's object, but in one's own personal orientation to impartiality, fairness and a willingness to give each person her due, including friend and enemy alike. ${ }^{47}$ Such fairness and impartiality does not militate against personal commitment. Quite to the contrary: these intellectual virtues presume such commitments, along with a willingness to contend fiercely for them. But they also offer a severe challenge to any ostensibly detached or impersonal approach to such knowing and commitment-which, to the oral-aural knower, may appear positively "irresponsible." ${ }^{48}$ So too in the context of Hindu-Christian and indeed all interreligious study and dialogue, our commitment to authentic objectivity may be best expressed neither by dogmatic 
insistence on the truth of our home traditions nor by cultivated neutrality, but by more relational virtues of fairness, impartiality and the widest possible accountability for our claims. ${ }^{49}$

In the penultimate chapter of his Presence of the Word, Walter J. Ong offers a profound reflection on "The Word and the Quest for Peace." This chapter follows several narrative threads and well reveals the complex interplay between orality and literacy in the contemporary world. In it, Ong may be read to suggest that only a combination of both sensoria is truly adequate for the wider human cause of peace, as literacy cools oral hostilities and orality unfixes the firm certitudes of literacy.

Right at the outset of the chapter, however, Ong begins with a beautiful, paradoxical reflection on the intrinsic orientation of even the most polemic speech toward peace:

The word moves toward peace because the word mediates between person and person. No matter how much it gets caught up in currents of hostility, the word can never be turned into a totally warlike instrument. So long as two persons keep talking, despite themselves, they are not totally hostile ... Hostile talk is hate in the midst of love manqué, or perhaps of wounded love..$^{50}$

This, I think represents a sound imperative for all theologians, scholars and committed persons working at the boundaries of religious traditions: keep talking, even if the talk is difficult, even if we are met by dismissal or hatred. For it is only in the dialogue between and among persons-no matter how contested-that true peace can be sought and, perhaps, even found.

\section{Notes}

${ }^{1}$ This article is a revised version of a paper I originally presented at an international symposium entitled, "McLuhan: Social Media Between Faith and Culture," on 21 September 2012. I am grateful to the organizers of that conference for the opportunity to formulate these ideas in a formal way; I also offer thanks for the very helpful questions and comments provided by participants at the conference, as well as by two anonymous reviewers for this journal.

${ }^{2}$ A description of these groups is available at "Bhagavad Gita Study Group," Arsha Vidya Gurukulam, <http://www.arshavidya.org/GitaHome-Study-Program.html>, accessed 21 February 2013.

${ }^{3}$ The roots of this program can be traced to the earlier development of study groups in the Chinmaya Mission, in which Swami Dayananda received his renunciant status and formation as an ācārya. See, for example, Swami Chinmayananda, A Manual of Self-Unfoldment (Mumbai: Central Chinmaya Mission Trust, 1975, 1976), 180-91.

${ }^{4}$ Among the growing literature on this topic, see C.J. Fuller and John Harriss, "Globalizing Hinduism: A 'Traditional' Guru and Modern Businessmen in Chennai," in J. Assayag and C. Fuller (eds.), Globalizing India: Perspectives from Below, (London: Anthem Press, 2005), 211-36. http://dx.doi.org/2027/mdp.39015063241486; and especially Maya Warrier, Hindu Selves in a Modern World: Guru Faith in the Mata Amritanandamayi Mission (London: RoutledgeCurzon, 2005). http://dx.doi.org/10.4324/9780203462065.

${ }^{5}$ Walter J. Ong, S.J., The Presence of the Word: Some Prolegomena for a Cultural and Religious 
History (New Haven: Yale University Press, 1967; Binghamton, NY: Global Publications, 2000), 75.

6 Walter J. Ong, Orality and Literacy: The Technologizing of the Word (London and New York: Routledge, 1982), 65-67. http://dx.doi.org/10.4324/9780203328064

7 See, e.g., ibid., 33-36, 57-64, as well as the discussion in Gavin Flood, An Introduction to Hinduism (Cambridge, New York and Melbourne: Cambridge University Press, 1996), 35-36; Michael Witzel, "Vedas and Upanișads," in The Blackwell Companion to Hinduism, ed. Gavin Flood (Oxford and Malden: Blackwell Publishing, 2003), 68-71. http://dx.doi.org/10.1002/9780470998694; and Patrick Olivelle, trans., The Early Upanișads: Annotated Text and Translation, South Asia Research Series (New York and Oxford: Oxford University Press, 1998), 8-10. http://dx.doi.org/2027/mdp.39015040174446

${ }^{8}$ Ong, Orality and Literacy, 66-67.

${ }^{9}$ Ong, Presence of the Word, 50.

${ }^{10}$ Ong, Orality and Literacy, 41-42.

${ }^{11}$ Ong, Presence of the Word, 231-36.

${ }^{12}$ Ibid., 52-53.

${ }^{13}$ Ong, Orality and Literacy, 68-69.

${ }^{14}$ Ibid., 45-46.

${ }^{15}$ Thomas J. Farrell, Walter Ong's Contributions to Cultural Studies: The Phenomenology of the Word and I'Thou Communication (Cresskill, NJ: Hampton Press, 2000), 29-30.

${ }^{16}$ Ong, Presence of the Word, 163-65.

${ }^{17}$ Ong, Orality and Literacy, 72.

${ }^{18}$ Ibid., 71-72, quotation at 72; Ong, Presence of the Word, 117-22.

${ }^{19}$ Ong, Presence of the Word, 125.

${ }^{20}$ Ong, Orality and Literacy, 72-73; Ong, Presence of the Word, 118-22,

${ }^{21}$ Ong, Orality and Literacy, 72.
22 I am following the text and translation available in Olivelle, Early Upanișads.

${ }^{23}$ J.G. Suthren Hirst, Śamkara's Advaita Vedānta: A Way of Teaching, RoutledgeCurzon Hindu Studies Series (London and New York: RoutledgeCurzon, 2005), 83-85.

${ }^{24}$ Paul J. Griffiths, Religious Reading: The Place of Reading and the Practice of Religion (New York and Oxford: Oxford University Press, 1999). http://dx.doi.org/10.1093/acprof:oso/97801951 25771.001 .0001

${ }^{25}$ Ibid., vii.

${ }^{26}$ E.g. Francis X. Clooney, Theology After Vedānta: An Experiment in Comparative Theology (Albany, NY: State University of New York Press, 1993); Seeing Through Texts: Doing Theology Among the Śrivaișnavas of South India (Albany: State University of New York Press, 1996). http://dx.doi.org/2027/mdp.39015038154244; Beyond Compare: St. Francis De Sales and Śrī Vedanta Desika on Loving Surrender to God (Washington, D.C.: Georgetown University Press, 2008).

${ }^{27}$ See Francis X. Clooney, S.J., "Contribution of Harold Coward to the Study of Religions and Hindu-Christian Studies," Hindu-Christian Studies Bulletin 15 (2002): 35-42. http://dx.doi.org/10.7825/2164-6279.1277

${ }^{28}$ See Harold Coward, Scripture in the World Religions: A Short Introduction (Oxford, Oneworld, 1988, 2000), ix. http://dx.doi.org/2027/mdp.39015043703845 and especially Harold G. Coward, "Traditional Sanskrit and Modern Scholarship: A Personal Journey," in Re-Imagining South Asian Religions: Essays in Honour of Professors Harold G. Coward and Ronald W. Neufeldt, ed. Pashaura Singh and Michael Hawley (Leiden and Boston: Brill, 2013), 3-14. 
90 Reid B. Locklin

${ }^{29}$ Coward, "Traditional Sanskrit," 5.

${ }^{30}$ Ibid., 7-8.

31 Ibid., 9-10; Coward, Scripture in the World Religions, ix-X, 113-16.

${ }^{32}$ Harold G. Coward and K. Kunjunni Raja, "Introduction to the Philosophy of the Grammarians," in Encyclopedia of Indian Philosophies V: Philosophy of the Grammarians (Delhi: Motilal Banarsidass, 1990), 33-50. http://dx.doi.org/2027/mdp.39015020794791

${ }^{33}$ Ibid., 37-38.

${ }^{34}$ Ibid., 44-48.

${ }^{35}$ Ibid., 48-50.

${ }^{36}$ Harold G. Coward and David J. Goa, Mantra: Hearing the Divine in India and America, $2 \mathrm{~d}$ ed. (New York: Columbia University Press, 2004), 5-

6.

37 Coward, Scripture, 188-89; cf. Clooney, "Contribution of Harold Coward," 39.

${ }^{38}$ Coward, Scripture, 161-68.

${ }^{39}$ Ibid., 181.

${ }^{40}$ Ibid., 179.

${ }^{41}$ Ibid., 178-82.

${ }^{42}$ Reid B. Locklin, Liturgy of Liberation: A Christian Commentary on Shankara's Upadeśasāhasrī (Leuven: Peeters, 2011), esp. 13-23.

${ }^{43}$ Ibid., 13-14, 249-85.

${ }^{44}$ Ibid., 289-97.

${ }^{45}$ Ong, Presence of the Word, 262-86.

${ }^{46}$ Ibid., 94-95, 300-301.

${ }^{47}$ Ibid., 222-23.

${ }^{48}$ Ibid., 243-46.

${ }^{49}$ See, e.g., the argument in Reid B. Locklin and Hugh Nicholson, "The Return of Comparative Theology," Journal of the American Academy of Religion $78 \quad$ (2010): 477-514. http://dx.doi.org/10.1093/jaarel/lfq017

${ }^{50}$ Ong, Presence of the Word, 192. 